\title{
Comparative analysis of the lists of hunting mammals of the countries of the Baltic region and Belarus
}

\begin{abstract}
Alexander P. Saveljev*, Andrey A. Lissovsky, Yuri A. Kozlov
ABSTRACT. The management of biological resources, which have important utilitarian value, should be based on current knowledge about their distribution, abundance, and taxonomic status. The data on the dynamics of distribution ranges and species abundance are easily available in the literature. However, it would seem that the simplest information - the lists of game species and their regional differences - is difficult for mammalogists to access. We compared the modern lists of hunting mammals of Estonia, Latvia, Lithuania, Poland, Belarus, and the bordering region of the Russian Federation with respect to their quantitative composition, structure and taxonomic verification. General trends and national features of the lists are noted. The recent and historical changes in the lists of objects of legal hunting are analysed.
\end{abstract}

How to cite this article: Saveljev A.P., Lissovsky A.A., Kozlov Y.A. 2020. Comparative analysis of the lists of hunting mammals of the countries of the Baltic region and Belarus // Russian J. Theriol. Vol.19. No.1. P.65-70. doi: 10.15298/rusjtheriol.19.1.06.

KEY WORDS: game mammals, hunting, Russia, Estonia, Latvia, Lithuania, Poland, Belarus.

Alexander P. Saveljev [saveljev.vniioz@mail.ru], Yuri A. Kozlov [kozlow.y@yandex.ru], Russian Research Institute of Game Management and Fur Farming, Preobrazhenskaya str. 79, Kirov 610000, Russia; Andrey A. Lissovsky [andlis@ zmmu.msu.ru], Zoological Museum of Moscow State University, Bolshaya Nikitskaya 6, Moscow 125009, Russia.

\section{Сравнительный анализ списков охотничьих млекопитающих государств Балтийского региона и Беларуси}

\begin{abstract}
А.П. Савельев*, А.А. Лисовский, Ю.А. Козлов
РЕЗЮМЕ. УПравление биологическими ресурсами, имеющими важное утилитарное значение, должно базироваться на современных представлениях об их распространении, численности и таксономическом статусе. Но если в литературе достаточно данных о динамике численности и ареалов охотничьих видов, то, казалось бы, самая простая информация - списки видов дичи и их региональные различия практически недоступна для териологов. Мы провели сравнение современных списков охотничьих видов млекопитающих Белоруссии, Латвии, Литвы, Польши, Эстонии и граничащих с ними районов Российской Федерации относительно их количественного состава, структуры и таксономической верификации. Отмечены общие тенденции и национальные особенности составления списков. Проанализированы исторические и современные изменения перечней объектов легальной охоты.
\end{abstract}

КЛЮЧЕВЫЕ СЛОВА: охотничьи мЛекопитающие, охота, Белоруссия, Латвия, Литва, Польша, Россия, Эстония.

\section{Introduction}

Currently, hunting retains an important role in most countries of Eastern Europe, North Asia and North America. In these regions, people are engaged in commercial hunting aimed at generating income, recreational hunting focused on social activities, including sport, and extermination hunting aimed at eliminating species that compete with agriculture or threaten human safety (Peterson, 2019). The most

\footnotetext{
* Corresponding author
}

hunted animals are mammals (hoofed and fur-bearers). Biodiversity conservation is a critical challenge at the national and global levels (Sponsel, 2000). Therefore, the sustainable use of mammal resources should be based on clear information not only about the fitness of populations, but also on the number of game species.

There are a huge number of insightful biological publications on the abundance, age and sex structure of game species populations. For example, the long-term (more than 100 years) species abundance dynamics (Reimoser et al., 2014) and dynamics at the scale of central Europe (Reimoser \& Reimoser, 2016) and even 
a continent (Collins et al., 2020) have been described in detail.

On the contrary, no attention has been paid to comparative studies of national game mammal lists. In the current study, we analysed the national game mammal lists of Estonia, Latvia, Lithuania, Poland, Belarus, and the bordering region of the Russian Federation in terms of their quantitative composition, structure, and taxonomic verification. We also noted the general trends and national features of the lists.

Several previous publications were devoted to analysis of the list of all hunting species in Russia (Fokin \& Blokhin, 2011; Linkov, 2012). Nevertheless a recent thorough analysis of the mammalian game species list made notable corrections (Saveljev et al., 2019). Some information on mammal game species status in the Baltic States was published by Timm et al. (1998). However the lists of mammals (the objects of legal hunting) in the whole region in question are compared in the current study for the first time.

\section{Current status of national lists}

Russia. Hunting of mammals in Russia is regulated by two federal laws (Federal Law "On fishing...", 2004; Federal Law "On hunting...", 2009). The list of game species includes 92 species with 4 insectivores, 5 lagomorphs, 20 rodents, 38 carnivores, 18 hoofed mammals, and 7 cetaceans (Saveljev et al., 2019). This list contains not only currently hunted mammals, but also a large group of species that were hunted historically, but have since lost their hunting value (mole, susliks, Eurasian water vole, hamsters, etc.) (Lissovsky et al., 2019). Thus the list of true mammalian game species is much shorter. Besides, according to Article 11, section 3 (Federal Law..., 2009), federal subjects can change game species lists. Game species lists for the Russian regions situated in the area of interest (Leningrad, Pskov, Smolensk, Bryansk, and Kaliningrad regions) include 33 species of mammals (Table). The number of game species varies between 19 (Pskov Region) and 30 (Leningrad Region).

Estonia. Hunting in this northernmost Baltic country is regulated by the Hunting Act adopted on 25 April 2013 (Eesti Jahiseadus, 2013). Paragraph 4 of this law contains a list of 20 mammal species and the permitted hunting period, with 8 big game and 11 small game species. In 2017, the golden jackal was included in the supplementary game list (Table).

Latvia. The list of Latvian game species is governed by the Hunting Rules, approved by the Decree of the Cabinet of Ministers of Latvia No.421 of 22 July 2014, last modified on 9 September 2016 (Medibunoteikumi, 2014). The list includes 24 species. Hunting of the six most valuable species is limited (quota), but nine species can be hunted without quantitative restrictions. In addition, the list contains nine other mammal species that are alien and/or atypical of the country's fauna. These alien mammals can be hunted all year round. The golden jackal is the only one among them that is invasive in status and is protected from the pursuit of hunters for a short breeding period (from April 1 to July 14). An atypical species in this group of animals is the bobak marmot, which for reasons undefined even to Latvian professionals, was included in the list after 2013. What is even more interesting is that with written permission, Latvian hunters can shoot dogs, cats, and escaped cattle all year round. The same rule applies to the Rackelhahn (hybrid between the black grouse Tetrao tetrix and the western capercaillie Tetrao urogallus).

Lithuania. The hunting rules for the territory Lithuania (Medžiokles Lietuvos Respublikos..., 2000) were adopted by the Order No. 258 of the Minister of the Environment of the Republic of Lithuania of 27 June 2000, last modified on 31 October 2008. The list of hunting species is not structured and formally includes 29 mammal species, but only 19 species can be hunted (Table). The "real" hunting species are: 5 species of hoofed mammals, 10 species of carnivores, the European hare, the Eurasian beaver, the muskrat, and the coypu.

Belarus. The hunting rules for Belarus were recently approved by the Presidential Decree No. 112 (About hunting and hunting husbandry, 2018). They came into effect on 25 September 2018. Fifty species of game animals (animals and birds), including 21 mammal species that can be hunted in this country, are listed in Appendix 1 to the Rules of hunting and hunting husbandry (Table). According to this list, 10 species are classified as standardized (including 8 hoofed, plus the Eurasian beaver and the Eurasian otter) and 11 non-standardized (not limited) fur-bearers. The European bison is also on the hunting list, but hunting is only allowed in terms of individuals from the "reserve gene pool".

Poland. The list of hunting mammals was determined by the Order of the Minister of the Environment (Rozporzadzenie Ministra Środowiska..., 2005) of 11 March 112005 (see Journal of Laws of 2005, No. 45, paragraph 433). The order came into effect on 17 August 2014. The list of hunting species contains 19 mammal species, including 7 species of big game (all hoofed mammals, including the moose, which are temporarily protected against hunting) and 12 species of small game (including 9 carnivores such as the red fox and the American mink and three species of rodents and lagomorphs - the muskrat, the European hare and the rabbit). What is interesting is that spring hunting of the muskrat coincides with hunting of the Eurasian woodcock.

In total, 24 mammal species can be hunted in Latvia, 21 in Belarus, 20 in Estonia, 19 in Lithuania and Poland, and 33 in neighbouring regions of Russia (Figure). For comparison: in the medieval Novgorod the Great (Novgorod Region, NW Russia) 17 wild species of mammals were hunted. The absolute record holder in terms of the number of bones remaining was the Eurasian beaver, followed by the moose, wild boar and mountain hare. Of the fur-bearing animals, squirrel and pine marten bones predominated. The remaining 
Table. Hunting status of mammalian game species in six countries. BG — big game, quotas assigned; SG — small game, without hunting quota; RY — hunting is allowed year-round (except for golden jackal breeding period in Latvia, see text); L - limited; NL — not limited; "_" — hunting is not allowed. Russian data is restricted to game species lists of Leningrad,

Pskov, Smolensk, Bryansk, and Kaliningrad regions.

\begin{tabular}{|c|c|c|c|c|c|c|}
\hline Mammal species & Russia & Estonia & Latvia & Lithuania & Belarus & Poland \\
\hline Moose Alces alces & $\mathrm{L}$ & BG & $\mathrm{L}$ & BG & $\mathrm{L}$ & $\mathrm{BG}$ \\
\hline European roe deer Capreolus capreolus & $\mathrm{L}$ & BG & $\mathrm{L}$ & $\mathrm{BG}$ & $\mathrm{L}$ & $\mathrm{BG}$ \\
\hline Red deer Cervus elaphus & $\mathrm{L}$ & $\mathrm{BG}$ & $\mathrm{L}$ & $\mathrm{BG}$ & $\mathrm{L}$ & $\mathrm{BG}$ \\
\hline Sika deer Cervus nippon & $\mathrm{L}$ & - & RY & $\mathrm{BG}$ & $\mathrm{L}$ & $\mathrm{BG}$ \\
\hline Fallow deer Dama dama & $\mathrm{L}$ & - & RY & $\mathrm{BG}$ & $\mathrm{L}$ & $\mathrm{BG}$ \\
\hline White-tailed deer Odocoileus virginianus & NL & - & - & - & - & - \\
\hline Mouflon Ovis aries & $\mathrm{L}$ & - & RY & $\mathrm{BG}$ & $\mathrm{L}$ & BG \\
\hline European bison Bison bonasus & - & - & - & $\mathrm{BG}$ & $\mathrm{L}$ & - \\
\hline Wild boar Sus scrofa & NL & $\mathrm{BG}$ & L & $\mathrm{BG}$ & $\mathrm{L}$ & $\mathrm{BG}$ \\
\hline Brown bear Ursus arctos & $\mathrm{L}$ & $\mathrm{BG}$ & - & $\mathrm{BG}$ & - & - \\
\hline Raccoon dog Nyctereutes procyonoides & NL & SG & RY & SG & NL & SG \\
\hline Red fox Vulpes vulpes & NL & SG & NL & SG & NL & SG \\
\hline American mink Neovison vison & NL & SG & RY & SG & NL & SG \\
\hline European mink Mustela lutreola & - & - & - & SG & - & - \\
\hline Eurasian lynx Lynx lynx & $\mathrm{L}$ & $\mathrm{BG}$ & $\mathrm{L}$ & $\mathrm{BG}$ & - & - \\
\hline Stoat Mustela erminea & NL & - & - & SG & - & - \\
\hline Western polecat Mustela putorius & NL & SG & - & SG & NL & SG \\
\hline Pine marten Martes martes & $\mathrm{NL}$ & SG & NL & SG & NL & SG \\
\hline Stone marten Martes foina & - & $\mathrm{SG}$ & NL & $\mathrm{SG}$ & NL & SG \\
\hline Least weasel Mustela nivalis & NL & - & - & SG & - & - \\
\hline Wolf Canis lupus & NL & $\mathrm{BG}$ & $\mathrm{L}$ & $\mathrm{BG}$ & NL & - \\
\hline Wolverine Gulo gulo & NL & - & - & - & - & - \\
\hline European badger Meles meles & $\mathrm{L}$ & SG & & SG & - & SG \\
\hline Eurasian otter Lutra lutra & $\mathrm{L}$ & - & - & - & $\mathrm{L}$ & - \\
\hline Raccoon Procyon lotor & - & - & $\mathrm{RY}$ & SG & - & SG \\
\hline Golden jackal Canis aureus & - & SG & RY & SG & - & SG \\
\hline Grey seal Halichoerus grypus & - & $\mathrm{BG}$ & - & - & - & - \\
\hline "Mole" Talpa sp. & NL & - & - & - & - & - \\
\hline Eurasian beaver Castor fiber & NL & SG & NL & SG & $\mathrm{L}$ & - \\
\hline North American beaver Castor canadensis & NL & - & - & - & - & - \\
\hline Red squirrel Sciurus vulgaris & NL & - & - & - & NL & - \\
\hline Siberian flying squirrel Pteromys volans & NL & - & - & - & - & - \\
\hline Coypu Myocastor coypus & - & - & $\mathrm{RY}$ & SG & - & - \\
\hline Bobak marmot Marmota bobak & - & - & RY & - & - & - \\
\hline "Susliks" Spermophilus spp. & NL & - & - & - & - & - \\
\hline Muskrat Ondatra zibethicus & NL & SG & NL & SG & NL & SG \\
\hline Eurasian water vole Arvicola amphibius & NL & - & - & - & - & - \\
\hline "Hamsters" Cricetinae gen. & NL & - & - & - & - & - \\
\hline Mountain hare Lepus timidus & NL & SG & NL & - & NL & - \\
\hline European hare Lepus europaeus & NL & SG & NL & SG & NL & SG \\
\hline Rabbit Oryctolagus cuniculus & - & - & - & - & - & SG \\
\hline
\end{tabular}

species were represented by single specimens (Maltby, 2012; Zinoviev, 2014). Thus, archaeozoological data indicates the strong centuries-old traditions of hunters in the region under consideration. A slight increase in the list of modern game species took place when some new species appeared in the region as a result of natural distribution expansion or introduction by humans.

\section{National peculiarities of hunting}

There are many widespread and numerous mammals that can be legally hunted in each of the countries listed above. The most popular species in the lists are the moose, the wild boar, the European roe deer, the red deer, the raccoon dog, the red fox, and some mustelids. 


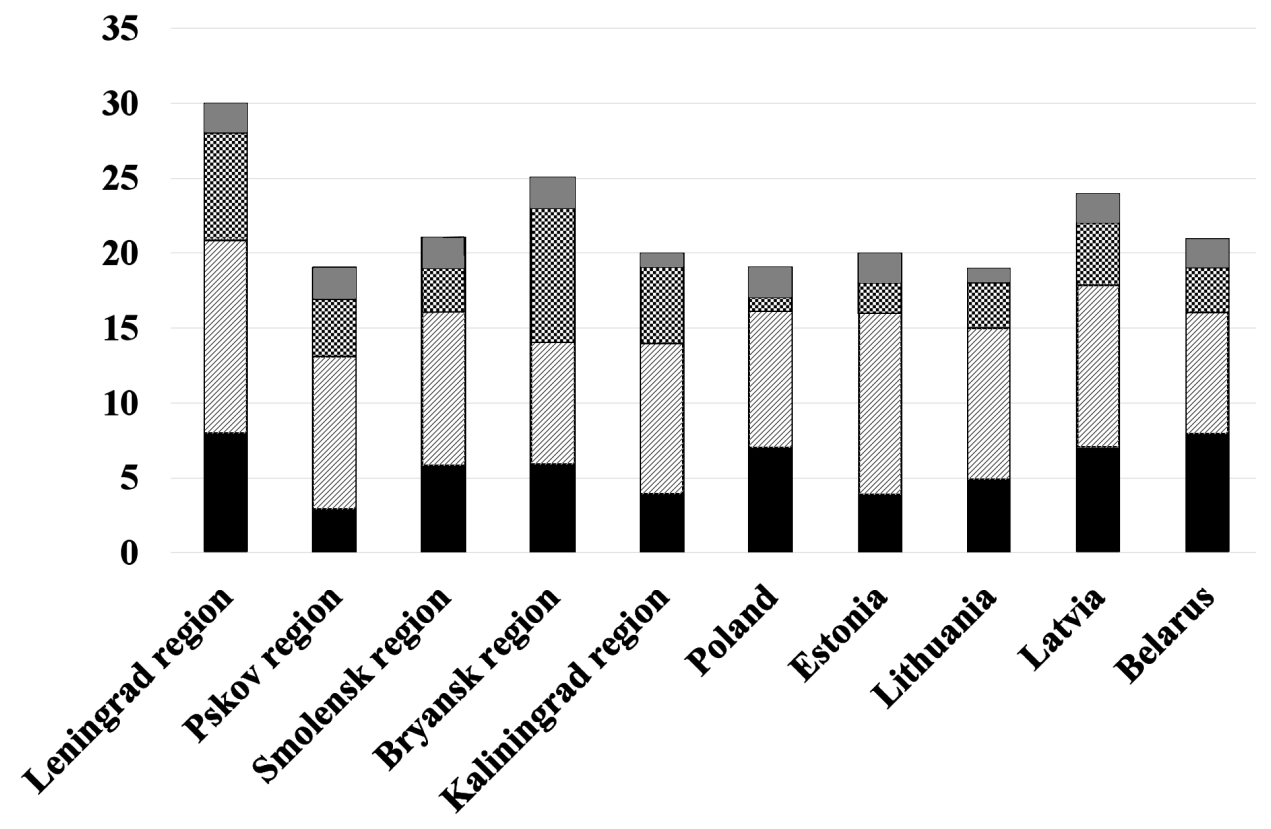

Fig. Different taxonomic groups of mammals in the hunting lists of Estonia, Latvia, Lithuania, Poland, Belarus, and bordering regions of the Russian Federation (black — hoofed mammals, oblique lines carnivores, chequered — rodents, grey — lagomorphs).

However, there are also country-specific features. For instance, only the Estonian list includes the harbour seal, while the Latvian list includes the bobak marmot, and the Lithuanian and Latvian lists include the coypu. The European mink, a globally threatened species, is still on the list of hunting animals in Lithuania. The Russian game species list includes several animals that were hunted historically, but are no longer hunted. These are the mole, susliks, the Siberian flying squirrel, the Eurasian water vole and hamsters. These species or groups of species are included in the Federal Law (2009) and some regional regulatory acts (Lissovsky et al., 2019).

\section{Taxonomic notes}

The lists we reviewed contain some invalid or misspelled Latin names of mammals. This is true for the Belarusian list (the fallow deer, the sika deer, the mouflon and the American mink), the Latvian list (the American mink and the mouflon), the Lithuanian list (the fallow deer) and the Polish list (the mouflon). The lists of game animals in the official documents of Estonia and the Russian Federation do not contain any scientific names of mammals. In addition, the official Russian game species list contains mixed groups without additional explanation: roe deer, mole, marmots, susliks, hamsters (Federal Law “On hunting...”, 2009; Lissovsky et al., 2019).

\section{Recent and upcoming changes}

In the twenty-first century, the golden jackal was included in the lists of hunting species in all Baltic States due to its rapid expansion to the north (Table). It was also included in the fauna of Poland (Kowalczyk et $a l ., 2015$ ) and in the list of its hunting species. In 2017, this carnivore was recorded in Belarus (Grichik et al., 2018), and prior to that in European Russia, near Saint Petersburg in 2007 and near Moscow in 2016 (see: http:// rusmam.ru/atlas/map). Recently a jackal invasion was recorded in Finland. The jackal will probably become a game species in these countries too.

Following its introduction to Finland in the twentieth century and breeding there, the white-tailed deer naturally emigrated in the mid-1990s to the neighbouring regions of NW Russia (Abramov \& Tikhonov, 2002). Since 2013, it has had the status of a hunting species in the Leningrad Region (On hunting and preservation of hunting resources ..., 2013). Currently, the Russian Hunting Department intends to recognize the white-tailed deer as a hunting resource at the federal level and has initiated a public discussion for this purpose (https:// regulation.gov.ru/p/96539).

Since 2019, Belarus has discussed the idea of including the Eurasian lynx in the list of hunting species. In Poland, the Eurasian beaver, the wolf and the Eurasian lynx are "preparing to leave" the protected species lists and to become limited hunting species. There is fierce public debate on each of the alleged changes. For instance, in Poland, the number of Eurasian beaver is 
steadily increasing. Today there are more than 130000 individuals. They annually cause damage to private landowners to the value of 30 million zlotys (Miszczuk, 2020). In accordance with the law, the damage caused by the Eurasian beaver to citizens is compensated by the Ministry of the Environment. This is probably the reason why hunters (represented by the Polish Union of Hunters) do not want to change the status of beaver to a hunting species, as the obligation to compensate for damage caused by beavers would pass to them. Nevertheless, looking ahead, Polish specialists have already published a guide to the integrated use of beaver resources and hunting products (Misiukiewicz, 2018). The Minister of the Environment of Poland even managed to issue an order (with prices on commercial hunting) on limited moose shooting, but after mass protests by scientists and the public, this document was cancelled. The selective commercial shooting of the European bison, a symbol of Poland and the subject of national pride, initiated by Polish foresters from time to time, also meets desperate resistance from local people.

In summary, our review of the lists shows that hunters of western regions of Russia, the Baltic States, Poland and Belarus have a similar choice of hunting objects. The composition of hunting objects has been relatively stable during the last few centuries, although it has been influenced by natural and human-induced changes in the fauna. It is necessary to align the scientific names of hunting species in national lists with the modern requirements of zoological nomenclature and systematics to successfully manage mammal resources and prevent possible errors in managerial decision-making.

ACKNOWLEDGEMENTS. We thank Mrs. Anite Upite, Dr. Harri Valdmann, Dr. Janis Ozolins, Dr. Alius Ulevicius, Dr. Grigori Yanuta and Mgr. Wojciech Misiukiewicz for their help in finding official legal hunting information. We thank two anonymous reviewers for their helpful comments and suggestions, which significantly improved the manuscript. The study was supported by the Russian Science Foundation (project No. 18-14-00093).

\section{References}

[About hunting and hunting husbandry. Order of the President of the Republic of Belarus]. 2018. http://rgooboor. by/f/pravila_okhoty_2018_indeks.pdf. Downloaded on November 16, 2019 [in Russian].

Abramov A.V. \& Tikhonov A.N. 2002. [Resources of hunting mammals in the western part of the Leningrad Region] // [Modern Problems of Nature Management, Hunting and Fur Animal Husbandry]. Proceedings of the International scientific-practical conference dedicated to the 80th anniversary of VNIIOZ. Kirov. P.114-116 [in Russian].

Collins A.C., Böhm M. \& Collen B. 2020. Choice of baseline affects historical population trends in hunted mammals of North America // Biological Conservation. Vol.242. P.108421.
Eesti Jahiseadus. 2013. https://www.riigiteataja.ee/ akt/129052013051. Downloaded on 16 November 2019.

[Federal Law No.209 "On hunting and wildlife protection" dated 24 July 24 2009]. Available at http://www.consultant. ru/document/cons_doc_LAW_89923 [in Russian].

[Federal Law No.166 "On fishing and protection of waterlife resources" dated 20 December 202004$]$. Available at http:// www.consultant.ru/document/cons_doc_LAW_50799/[in Russian].

Fokin S.Yu. \& Blokhin Yu.Yu. 2011. [The list of objects of the animal world related to the objects of hunting of the Russian Federation] // State Resource Management. Special Issue. P.130-143 [in Russian].

Grichik V.V., Prakapchuk V.V., GrebenchukA.E., Rabtsava A.A. \& Tsybovsky I.S. 2018. [Golden jackal (Canis aureus L., 1758) - a new species in the theriofauna of Belarus] // [Journal of the Belarusian State University. Biology]. No.3. P.55-61 [in Russian with English summary].

Kowalczyk R., Kołodziej-Sobocińska M., Ruczyńska I. \& Wojcik J.M. 2015. Range expansion of the golden jackal (Canis aureus) into Poland: first records // Mammal Research. Vol.60. P.411-414.

Linkov A.B. 2012. [Hunting animals; lists and their structuring, identification of potential units of hunting, problems and prospects of population management] // The Herald of Game Management (Vestnik Ohotovedenia). Vol.9. No.1. P.111-120 [in Russian with English summary].

Lissovsky A.A., Sheftel B.I., Saveljev A.P., Ermakov O.A., Kozlov Yu.A., Smirnov D.G., Stakheev V.V. \& Glazov D.M. 2019. Mammals of Russia: Species List and Applied Issues. Archives of Zoological Museum of Moscow State University. Vol.56. Moscow: KMK Scientific Press. 191 p.

Maltby M. 2012. From Alces to zander: A summary of the zooarchaeological evidence from Novgorod, Gorodishche and Minino // The Archaeology of Medieval Novgorod in Context: A Study of Centre/Periphery Relations. Oxford: Oxbow Books. P.351-380

Medībunoteikumi. 2014. https://likumi.lv/doc.php?id=267976. Downloaded on 16 November 2019.

Medžiokles Lietuvos Respublikos Teritorijoje Taisykles. http:// www.lmzd.lt/lt/medziokle/teise/medziokles-taisykles. Downloaded on 16 November 2019.

Miszczuk H. 2020. Łowca Bobrów. https://swiatrolnika.info/ publicystyka/firma-bobry-odlawianie. Downloaded on 28 January 282020.

Misiukiewicz W. 2018. Vademecum Bobrowe. Suwalki: BTL Works. 152 p. Available athttp://www.vademecumbobrowe.pl.

[On hunting and preservation of hunting resources in the Leningrad Region. 2013. Law of the Leningrad Region of 21 June 2013 No.35 (as amended on 16 March 2017)]. http://docs.cntd.ru/document/537936975. Downloaded on 16 November 2019 [in Russian].

Peterson M.N. 2019. Hunting // Fath B. (ed.). Encyclopedia of Ecology. $2^{\text {nd }}$ edn. Vol.3. Amsterdam: Elsevier. P.438-440.

Reimoser F. \& Reimoser S. 2016. Long-term trends of hunting bags and wildlife populations in Central Europe // Beiträge zur Jagd- und Wildforschung. Vol.41. P.29-43.

Reimoser S., Smidt S., Reimoser F. \& Wildauer L. 2014. Entwicklung von Jagdstrecken und Lebensraum im suedlichen Wienerwald seit 1891 // Allgemeine Forst- und Jagdzeitung. Vol.185. No.1-2. P.16-27. 
Rozporządzenie Ministra Srodowiska ... w sprawie ustalenia listy gatunków zwierząt łownych. 2005. http://prawo.sejm. gov.pl/isap.nsf/DocDetails.xsp?id=WDU20050450433 Downloaded on 16 November 2019.

Saveljev A., Strelnikov D., Ekonomov A., Kozlov Yu., Glazov D. \& Lissovsky A. 2019. [Game animals in the project "Atlas of Russian mammals distribution": Goals, first results and difficulties] // The Herald of Game Management (Vestnik Okhotovedenia). Vol.16. No.1. P.29-36 [in Russian with English summary].
Sponsel L.E. 2000. Human impact on biodiversity // Levin S.A. (ed.). Encyclopedia of Biodiversity. Vol.3. New Jersey: Academic Press. P.395-409.

Timm U., Pilats V. \& Balciauskas L. 1998. Mammals of the East Baltic // Proceedings of the Latvian Academy of Sciences, Section B. Vol.52. No.1-2. P.1-9.

Zinoviev A.V. 2014. [Hunting mammals of the medieval Novgorod the Great (according to the archaeozoological data)]// [Proceedings of the Tver State University. Biology \& Ecology]. No.4. P.86-94 [in Russian with English summary]. 